\title{
Wireless Mobile Spectrum Assignment in India: Issues and Challenges
}

\author{
Hansikaa Chauhan ${ }^{1}$, Dr. Archana Sarma ${ }^{2}$ \\ ${ }^{1}$ Research Scholar Ph.D., The NorthCap University, India. \\ ${ }^{2}$ Dr. Archana Sarma, Associate Professor \& Head, School of Law, The NorthCap University, India
}

\begin{abstract}
The research paper discusses and analyzes the Wireless Mobile Spectrum Assignment in India during the recent spectrum auction held in March 2021. India is today the second largest and the fastest growing telecom industry in the world in terms of number of wireless connections and is steering towards technological advancements in wireless mobile communications. With the introduction of Digital India Programme, the Wireless Mobile Communications Industry promises to place India on a strong footing with other developed economies of the world in the near future. However, the Industry has been facing several roadblocks on its way to the future growth due to inefficient spectrum management. In this paper, the Researchers have discussed the significance and contribution of the Wireless Mobile Spectrum in the economic growth of India and have critically analyzed the Wireless Spectrum Assignment process. The Researchers have also highlighted the performance indicators of Wireless Cellular Mobile Communications Industry in order to emphasize on the importance of spectrum management in the growth and development of this industry. The researchers have highlighted the various issues and challenges in Spectrum Allocation of India and have given suggestions for efficient spectrum management before the next 5G Auction in the Year 2022 that can further accelerate India towards 'Digitalization' and Globalization.
\end{abstract}

Keywords: Spectrum Auctions in India, 5G Spectrum Bands, Digital India, Mobile Economy, Doing Business in India. 


\section{Introduction}

"It is precisely in places where no infrastructure exists that wireless can be particularly effective, helping countries to leapfrog generations of telecommunications technology and infrastructure and empower their people."

\section{- (Mr. Kofi Annan, UN Secretary- General)}

The wireless cellular mobile communications industry has achieved an exemplary growth in the last decade in India. With 1,153.77 million ${ }^{3}$ wireless mobile subscriptions at the end of third quarter of the year 2020, India is today the second largest and the fastest growing telecom industry in the world in terms of number of wireless connections. It is noteworthy that the Indian Mobile Subscribers base has grown more than forty times from 28.50 million ${ }^{4}$ subscribers in December 2003 to $1,153.77$ million in December $2020^{5}$.

Currently, India is steering towards technological advancements in wireless mobile communications and is striving to create a suitable infrastructure for $5 \mathrm{G}$ technology. While $2 \mathrm{G}$ technology was being used predominantly for voice services in the last decade, at present the data intensive LTE technologies, has converted mobile handsets into a converged device which is capable to provide all communication requirements of a smartphone user, which is- voice, data, information, music and entertainment. Therefore, in order to further expand and improve country's wireless cellular mobile communication, it is imperative to use the spectrum efficiently because data applications consume more bandwidth as compared to voice communications.

Radio Spectrum being a scarce and limited natural resource, futuristic spectrum planning and policies play a significant role in ensuring the efficient use of spectrum that will not only benefit the Government but also Network Operators as well as the consumers. The phenomenal growth of the wireless mobile communication industry in the last decade was a result of policy and regulatory reforms that paved the way for privatization, foreign direct investment, low mobile- tariff costs, development of telecom infrastructure, unified licensing etc. thereby enabling faster wireless mobile penetration in the country. Technological advancement and evolution are completely dependent upon the availability of required spectrum at an affordable price and therefore futuristic spectrum planning, appropriate spectrum pricing, efficient spectrum allocation and utilization are necessary for a continuous growth of this industry. There is no doubt that RF Spectrum is and has always been a crucial factor in the evolution of Indian wireless mobile communication industry and is a significant contributor to National Gross Domestic Product (GDP). It is RF Spectrum that infuses life to the wireless mobile communication industry. According to a recent World Bank study that correlates GDP growth

\footnotetext{
3 The Telecom Regulatory Authority of India. (2021, April). The Indian Telecom Services Performance Indicators Oct-Dec 2020 p. 13 https://trai.gov.in/sites/default/files/QPIR_27042021_0.pdf

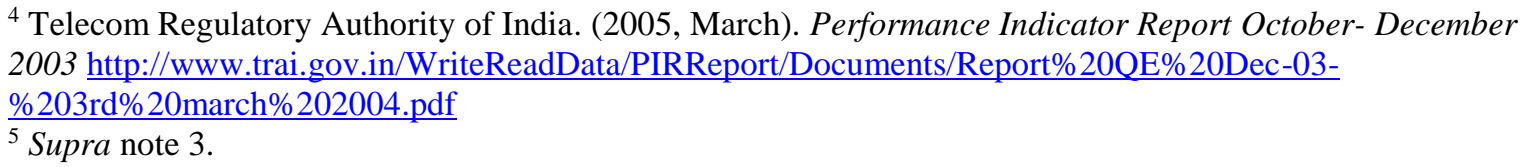


with fixed, mobile, internet and broadband adoption a 10-percentage point increase in mobile penetration could generate a 0.81 percentage point increase in GDP growth in low-to-middle income countries, and a 0.60 percentage point increase in high-income countries ${ }^{6}$. The result for broadband adoption is even more promising: a 10-percentage point increase in penetration yields a 1.38 percentage point increase in GDP growth in low-to-middle income countries, versus 1.21 percentage points in high-income countries ${ }^{7}$. That is the reason why French jurist J.D. Bedin has defined the frequency spectrum as technology, industry, money, culture, and power ${ }^{8}$.

\section{Significance of spectrum in the economic growth of india}

Globally, it took 113 years for the wireline tele density to reach $1 / 10^{\text {th }}$ of the world's population whereas wireless mobile achieved the same tele density within first fifteen years ${ }^{9}$. In developed as well as developing countries, wireline is being replaced by wireless mobile communications service that has been recognised as a public utility. Similarly, in India, a weak and inadequate fixed line infrastructure opened the doors for wireless mobile communication services to streak ahead of wireline connections. As a result, the mobile subscriber base in India crossed the wireline subscriber base in October $2004^{10}$ and currently overshadows the wireline industry by a ratio of around $58: 1^{11}$. From the above statistics, it is evident that in the present scenario, growth of telecommunication sector is synonymous with growth of wireless mobile communication services. Wireless is the driving force behind the growth of telecommunication sector which is accelerated by $R F$ Spectrum- 'the heart and soul' of wireless cellular mobile communication.

The wireless mobile communication industry has become a significant contributor to Indian economy in the past two decades. The share of telecommunication services (excluding postal and miscellaneous services) to the country's GDP has increased from $0.96 \%$ in $2000-01$ to $6.5 \%$ at present with a total contribution of INR 9 lakh crore to the economy ${ }^{12}$. Currently,

\footnotetext{
${ }^{6}$ Christine Zhen-Wei Qiang. (2009, November). Mobile Telephony - A Transformational Tool for Growth and Development, PROPARCO'S MAGAZINE, Issue 4 November 2009, at 8. Available: https://blog.private-sectorand-development.com/2009/12/21/mobile-phone-a-transformational-tool-for-growth-development/

${ }^{7}$ Michael Minges. (2015). Exploring the Relationship between Broadband and Economic Growth. World Bank. https://documents1.worldbank.org/curated/en/178701467988875888/pdf/102955-WP-Box394845B-PUBLICWDR16-BP-Exploring-the-Relationship-between-Broadband-and-Economic-Growth-Minges.pdf

${ }^{8}$ Centre for Strategic and International Studies. (1991, September 19). The New Spectrum Mudwrestle: WARC 1992 and Beyond (Washington D.C.: CSIS International Communications Studies, Symposium, 1992), (p. vi).

${ }^{9}$ Telecom Regulatory Authority of India. Government of India. (2005, May 13). Recommendations on Spectrum related Issues p. 22. https://www.trai.gov.in/sites/default/files/spectrumreco.pdf

${ }^{10}$ Telecom Regulatory Authority of India. Government of India. (2005, March). Performance Indicator

Report October- December 2004

http://www.trai.gov.in/WriteReadData/PIRReport/Documents/report22mar05.pdf

${ }^{11}$ Supra 3 at 24 . Total Wireless subscriptions by Oct. 2020 is 1,153.77 million whereas wireline subscription was 20.05 million.

${ }^{12}$ Invest India- National Investment Promotion and Facilitation Agency. (2021, June). Telecom Sector https://www.investindia.gov.in/sector/telecom
} 
the industry directly and indirectly has been supporting more than 4 million jobs ${ }^{13}$ which is likely to increase rapidly once the Covid- 19 situation subsides.

\section{Wireless Spectrum Policy of India- A Critical Analysis}

Effective Spectrum Management, Efficient Spectrum Utilization and Appropriate Spectrum Pricing are the three key factors that can accelerate the growth of Indian Wireless Cellular Mobile Communications Industry. If the Government handles these three factors wisely then it can easily remove the uncertainties and ambiguities that have affected the growth and foreign direct investment in this Sector

India requires more spectrum to capture the advantages of new opportunities for social and economic development. With demands for mobile technology expected to rise rapidly in future years, it is imperative that the country deploy spectrum for commercial utilization in order to make possible the expansion of mobile broadband.

The National Telecom Policy- $2012^{14}$ (hereinafter referred to as NTP- 2012) laid down the following provisions related to Spectrum Assignment for faster adoption of advanced mobile technologies-

i. To simplify the licensing framework,

ii. To create One Nation- One License across services and service areas

iii. To provide adequate spectrum and its allocation in a transparent manner and to delicense additional spectrum for commercial use.

iv. To harmonize legal, regulatory and licensing framework for efficient converged services.

v. To establish a unified licensing regime and de-link spectrum for all future licenses.

vi. To make spectrum technology- neutral and allow spectrum pooling, sharing and trading.

vii. To enable spectrum refarming to make more spectrum available for newer technologies and

viii. To provide adequate $1800 \mathrm{MHz}, 1910 \mathrm{MHz}, 2.1 \mathrm{GHz}, 2.3 \mathrm{GHz}, 2.5 \mathrm{GHz}$ and 3.5 $\mathrm{GHz}$ bands for commercial mobile services.

Despite having such promising provisions, NTP- 2012 could not yield the desired results due to the delay in implementation of policies related to its objectives.

With so many opportunities available in India, it is crucial to address the current barriers. There have been a number of difficulties in terms of India's spectrum policy which includes challenges related to poor spectrum planning, availability and cost of spectrum, fragmented

\footnotetext{
${ }^{13}$ Ibid.

${ }^{14}$ Department of Telecommunications, National Telecom Policy- 2012. Ministry of Communications. Government of India. https://dot.gov.in/sites/default/files/NTP-06.06.2012-final_0.pdf
} 
spectrum bands, and failed past auctions interalia. The following sections outline each of these issues in greater detail.

\subsection{Challenges in Efficient Allocation of Spectrum in India}

Spectrum Management is the process of regulating the use of radio frequencies to promote efficient use and gain a net social benefit ${ }^{15}$. As discussed above, Spectrum Management is an amalgamation of administrative and technical procedures with legal regulations that are needed to ensure an efficient working of radio communication services without causing any harmful interference.

While managing spectrum, the Government deals with two types of efficiency- technical and economic that are achieved in conformity with the principles of public policy. Technical efficiency denotes an optimal use of spectrum with minimum interference within permissible limits. It also aims to develop spectrum-saving technologies. Whereas, Economic efficiency is achieved by developing methods which support spectrum assignment and allocation to uses that are capable to gain highest economic return from it. At the same time, the regulatory process of achieving the objectives of technical and economic efficiency has to be reasonably flexible and adaptable to modifications that take place due to technological advancements and change in market value of resources.

The process of Spectrum Management is multi-dimensional in nature which includes interalia, a proper frequency and band planning before auctions, spectrum refarming, calculation of resources before determining the reserve price of spectrum, efficient spectrum auctions, effective policies with well-defined objectives, timely allocation of spectrum, spectrum engineering, standardization of telecom equipment and control and monitoring of spectrum.

If the above- mentioned parameters claim to be the hallmark of efficient spectrum management, then there is no doubt in the fact that the current state of the Indian Wireless Cellular Mobile Communication Industry is a clear reflection of mismanagement of spectrum by public as well as private sector. The problems faced by this industry have cropped up due to the mismanagement of this limited resource. Spectrum engineering and management are the heartbeats which infuse life into this Industry. Therefore, it is imperative that this heart functions efficiently so as to avoid a myocardial infarction of the wireless cellular mobile communication industry.

The various challenges of spectrum planning have been discussed in detail below in the context of Wireless Cellular Mobile Communications Industry of India-

\subsubsection{Uneven Spectrum Band Planning before Auctions}

Spectrum Planning is the first step in the process of spectrum management which is very crucial for efficient utilization of spectrum. To avoid wastage of spectrum, it is pertinent that

${ }^{15}$ Martin Cave et al. (2007). Essentials of Modern Spectrum Management. Cambridge University Press. 
at the national level, spectrum bands are engineered in such a manner that they are harmonized with international standards and are not fragmented so that advanced technologies like LTE (4G) and $5 \mathrm{G}$ can be rolled out smoothly.

Table 1 given below shows the Frequency Bands in which the cellular operators provide different mobile technologies. These bands are auctioned by the Government from time to time as per the market requirement in various Licensed Service Areas (LSA's).

However, the operators have not been able to use these bands to their full potential due to fragmented possession of these bands that obstructed their optimum use.

Table 1: Wireless Cellular Mobile Communication Services have been allotted the following bands in India ${ }^{16}$

\begin{tabular}{|c|c|c|c|}
\hline Band & Band Name & Technology & Frequency Allotted (in $\mathrm{MHz}$ ) \\
\hline $800 \mathrm{MHz}$ & CDMA & 2G/LTE- FDD & 824- 844/ 869- 889 \\
\hline $900 \mathrm{MHz}$ & $\begin{array}{c}\text { GSM/ n8- 5G } \\
\text { NR Band }\end{array}$ & $\begin{array}{c}\text { 2G/UMTS/ } \\
\text { HSPA/ } \\
\text { WCDMA/ LTE } \\
(4 \mathrm{G}) / 5 \mathrm{G}\end{array}$ & 890- 915/ 935- 960 \\
\hline $1800 \mathrm{MHz}$ & $\begin{array}{c}\text { GSM/ 3GPP } \\
\text { Band B3 }\end{array}$ & 2G/LTE- FDD & $1710-1785 / 1805-1880$ \\
\hline $2100 \mathrm{MHz}$ & $\begin{array}{c}\text { 3GPP Band B1/ } \\
\text { UMTS }\end{array}$ & $\begin{array}{l}\text { UMTS (3G)/ } \\
\operatorname{LTE}(4 G)\end{array}$ & 1920- 1980/ 2110- 2170 \\
\hline $2300 \mathrm{MHz}$ & $2.3 \mathrm{GHz}$ Band & $\begin{array}{c}\text { TD- LTE }(4 \mathrm{G}) / \\
5 \mathrm{G}\end{array}$ & 2300- 2400 \\
\hline $2500 \mathrm{MHz}$ & 3GPP B41 & TD- LTE (4G) & 2500- 2690 \\
\hline
\end{tabular}

\footnotetext{
${ }^{16}$ Wireless Planning and Coordination Wing. (2011, September). National Frequency Allocation Plan 2011 p. 194. Department of Telecommunications. Ministry of Communications and Information Technology. Government of India.

https://www.coai.com/sites/default/files/National-Frequency-Allocation-Plan-NFAP-2011_0_0_0.pdf
} 


\section{SOCIAL SCIENCES IN THE 21ST CENTURY}

Source: Wireless Planning and Coordination Wing. Department of Telecommunications. Government of India.

India has been divided into 22 Telecom Circles, wherein 3 circles cover the Metros, namely, Delhi, Mumbai and Kolkata and the remaining 19 circles cover other States of India. These Circles are further divided into A, B and C category based on economic parameters and revenue potential. At present, India has three major private operators with pan- India networks across different frequency bands.

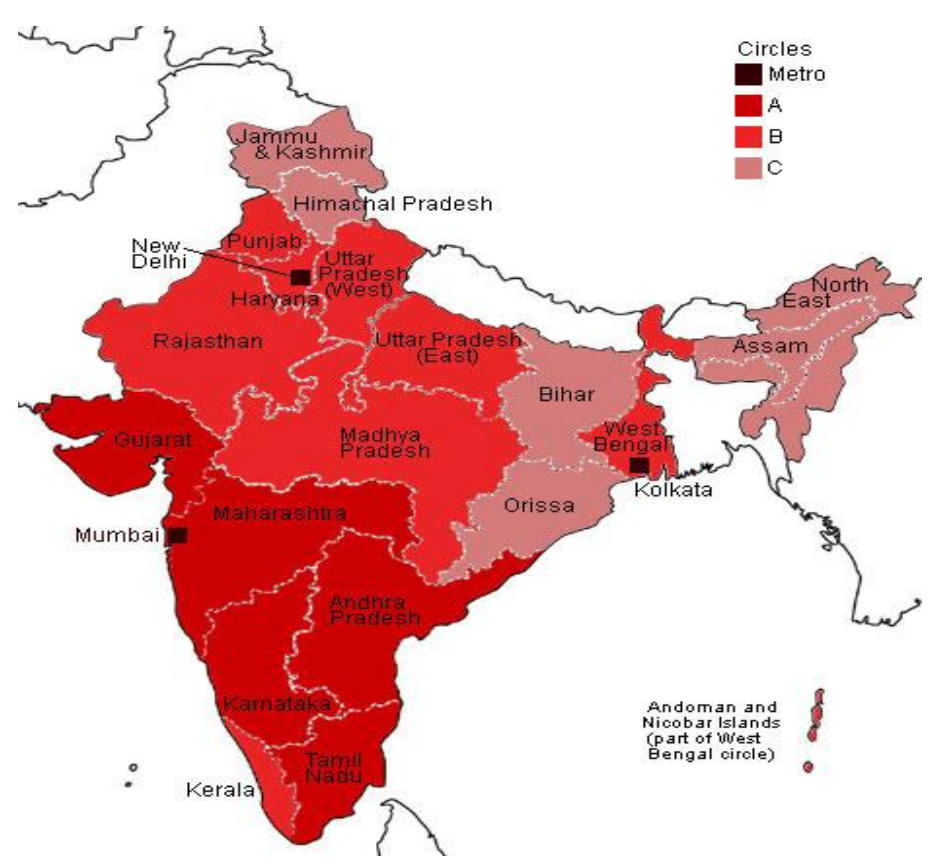

Figure 1: Telecom Circles in India ${ }^{17}$

Due to uneven Frequency and Band planning for 2G, 3G and 4G technologies each operator in a given band was allotted with different frequencies channels in all the circles for which he obtained a license. This made active sharing as well as passive sharing a challenge thereby increasing the cost of rolling out networks.

Before the introduction of unified licensing guidelines in India, each spectrum band used to signify a specific technology that could be deployed only in that particular band. For example, as shown in Table: 1 above, $800 \mathrm{MHz}$ band was used for CDMA technology whereas 900/1800 MHz Bands were used only for $2 \mathrm{G}$ mobile communications. Similarly, $2100 \mathrm{MHz}$ Band was used for $3 \mathrm{G}$ mobile communication and 2300/2600 MHz Bands were used for 4G technology. Before 2014, on an average, around 6-8 operators used to operate in each spectrum

\footnotetext{
${ }^{17}$ Catherine Haslam. (2016, November 29). A Guide to India's Telecom Market, India Calling Info. http://www.indiacallinginfo.com/india-telecom-circles
} 
band in a specific technology in a given circle. For example, in December 2013 there were 8 Service Providers in the Delhi circle who were operating in the $1800 \mathrm{MHz}$ Band namely, Airtel, Vodafone, Idea, Aircel, R. Com, Tata Teleservices, Sistema Shyam and MTNL and till October 2014 they all were operating only $2 \mathrm{G}$ Technology in that band.

However, after the introduction of Unified Licensing Guidelines in November 2014, the Indian Telecom Sector was made open to unified licensing under which any Telecom Service Provider could operate any technology in a given Band in a given telecom circle. In other words, spectrum was made technology- neutral but due to the fragmented spectrum in all the prominent bands for LTE technology, $4 \mathrm{G}$ could not be used to its full capacity in India.

So, now under the Unified Licensing regime, some operators like Airtel, Vodafone Idea Limited (VIL) had been successful in deploying 2G as well as LTE (4G) technologies in the $1800 \mathrm{MHz}$ Band whereas there were some Service Providers who were limited to only $2 \mathrm{G}$ technology in that Band due to unavailability of contiguous spectrum. Similarly in the 900 MHz band, 2G and UMTS (3G) technologies have been deployed by a few Service Providers while some operators have been made bound to restrict themselves to just the $2 \mathrm{G}$ technology due to fragmented spectrum in those bands.

It is pertinent to mention here, that $1800 \mathrm{MHz}$ is the most suitable band for LTE (4G). According to Global Mobile Suppliers Association (GSA), presently $1800 \mathrm{MHz}$ Band covers $68 \%$ of the total LTE networks by being used by 811 network operators globally. ${ }^{18}$

The implications of improper spectrum planning can be further understood with the help of following Cases wherein the current frequency allocation in the two metros has been highlighted in the 900, 1800, 2100 and $2300 \mathrm{MHz}$ band after the 2015 Spectrum Auction.

\section{CASE 1- Delhi circle, $1800 \mathrm{MHz}$ band-}

The below given Table 2 shows the frequencies allotted to Airtel in the $1800 \mathrm{MHz}$ Band in Delhi in the Spectrum Auction, 2015.

After the spectrum allocation in February, 2015 auction, Airtel had 4 chunks of $0.2 \mathrm{MHz}$, $0.8 \mathrm{MHz}, 0.4 \mathrm{MHz}$ and $4.8 \mathrm{MHz}$ frequency in the $1800 \mathrm{MHz}$ band in Delhi. However, despite having a total spectrum of $6.2 \mathrm{MHz}$ in this circle, the Operator was unable to deploy LTE (4G) technology in the $1800 \mathrm{MHz}$ and was bound to roll out only the $2 \mathrm{G}$ technology in that band due to fragmented spectrum. So, to roll- out LTE in Delhi, Airtel had to buy a contiguous block of spectrum in the $2300 \mathrm{MHz}$ band thereby increasing its debt burden.

18 Global Mobile Suppliers Association. (2021, June 30). Status of the LTE Ecosystem p. 5. https://gsacom.com/reports/ 


\section{SOCIAL SCIENCES IN THE 21ST CENTURY}

Table 2: Frequencies allotted to Airtel in the $1800 \mathrm{MHz}$ Band in Delhi in Spectrum Auction $2015^{19}$
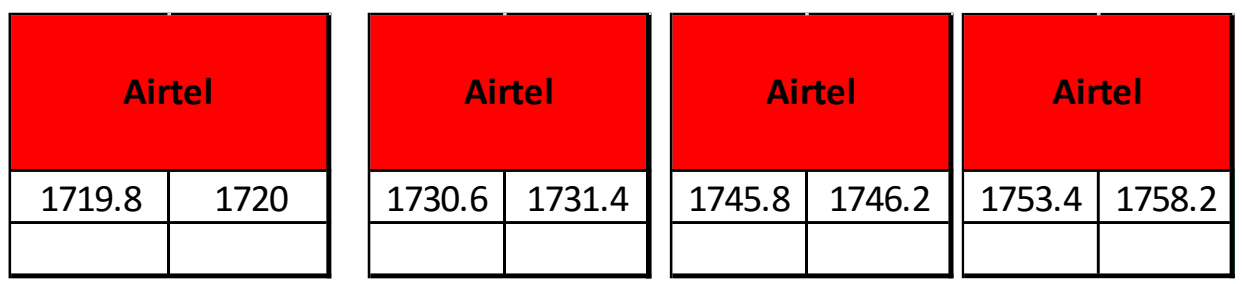

Source: Wireless Planning and Coordination Wing. (2015, January 31). Spectrum Holding of Telecom Service Providers

The above case is a staunch example of poor spectrum planning which ultimately led to misutilization of spectrum and an increase in network roll- out costs, to overcome which Operators had to raise the consumer tariffs.

\section{CASE 2- The $900 \mathrm{MHz}$ Band in the Kolkata Circle-}

Table 3 shows the frequency planning in the $900 \mathrm{MHz}$ Band in the Kolkata Circle. In Kolkata, total spectrum held by Airtel was $6.9 \mathrm{MHz}$ which is fragmented into $4.9 \mathrm{MHz}$ and 2 $\mathrm{MHz}$ while Vodafone has three chunks of $4.9 \mathrm{MHz}, 2 \mathrm{MHz}$ and $0.6 \mathrm{MHz}$ which makes it a total $7.5 \mathrm{MHz}$ of spectrum. Here both the Operators are able to roll- out $2 \mathrm{G}$ and UMTS (3G) technology but both the Service Providers had to work on technical configurations in their networks because they had not been allotted contiguous blocks of spectrum in the $900 \mathrm{MHz}$ band.

Table 3: Frequencies allotted to Airtel \& Vodafone in the $900 \mathrm{MHz}$ Band in Kolkata 20

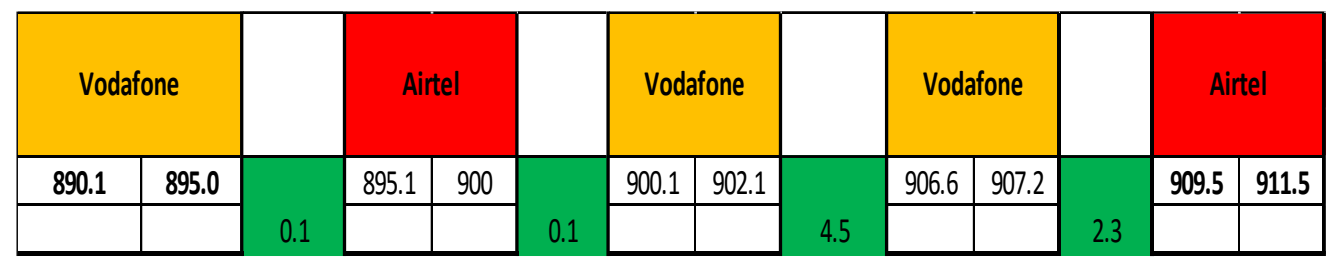

Source: Wireless Planning and Coordination Wing. (2015, January 31). Spectrum Holding of Telecom Service Providers

CASE 3 - Delhi Circle, 900, 1800, 2100 \& 2300

\footnotetext{
${ }^{19}$ Wireless Planning and Coordination Wing. (2015, January 31). Spectrum Holding of Telecom Service Providers

http://www.wpc.gov.in/WriteReadData/Orders/spectrum\%20holding\%20as\%20on\%20January\%2031 \%20201 $\underline{5 . p d f}$

${ }^{20} \mathrm{Ibid}$.
} 
Table 4 below, shows spectrum held by Airtel in the $900 \mathrm{MHz}, 1800 \mathrm{MHz}, 2100 \mathrm{MHz}$ and $2300 \mathrm{MHz}$ band in the Delhi Circle.

Table 4: Spectrum held by Airtel in the $900 \mathrm{MHz}, 1800 \mathrm{MHz}, 2100 \mathrm{MHz}$ and $2300 \mathrm{MHz}$ band in Delhi Circle $\mathrm{B}^{21}$
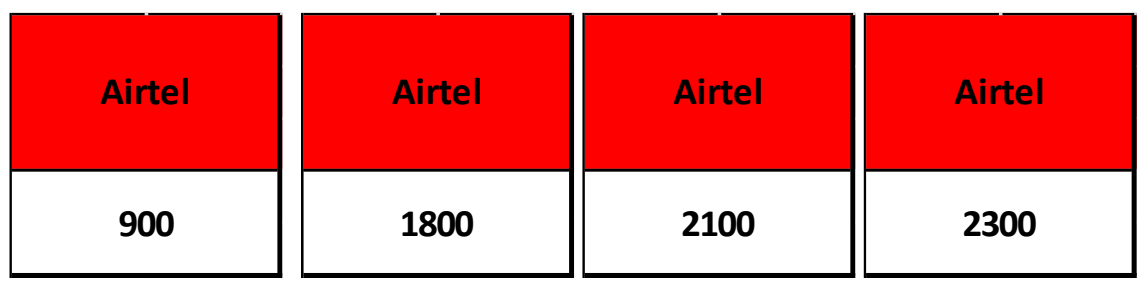

Source: Wireless Planning and Coordination Wing. (2015, January 31). Spectrum Holding of Telecom Service Providers

The spectrum in all the above-mentioned bands was acquired by Airtel before 2014 i.e., before the unified licensing was allowed in India. Before 2014, Airtel had been using 900/1800 $\mathrm{MHz}$ for 2G, $2100 \mathrm{MHz}$ band for UMTS (3G) and $2300 \mathrm{MHz}$ band for LTE technology. Before the unified licensing regime, the Service Provider had to buy spectrum in different bands in order to deploy different technologies that were compatible with a specific band.

However, after the introduction of unified licensing guidelines in the year 2014, Airtel had to roll-out 2G/ 3G in $900 \mathrm{MHz}$ band, 2G/ 4G in $1800 \mathrm{MHz}$ Band, 3G in $2100 \mathrm{MHz}$ band and $4 \mathrm{G}$ in $2300 \mathrm{MHz}$ band since contiguous block of spectrum was unavailable in the $1800 \mathrm{MHz}$ band.

The above discussed cases explain the significance of proper spectrum band planning and how dispersed spectrum restricts operators from deploying multiple technologies in a given band which results in under-utilization and misutilization of spectrum which is a valuable and a limited resource.

\subsubsection{Inadequate Availability of Spectrum}

Availability of required spectrum is another constraint as there are insufficient bands for the ever- increasing wireless mobile demands in India. As shown in Table 5, the availability of licensed spectrum in India is much lower than the U.S. and Europe, and also significantly lower than other developing countries like Brazil and China.

\footnotetext{
${ }^{21}$ Ibid.
} 


\section{SOCIAL SCIENCES IN THE 21ST CENTURY}

Table 5: Total Licensed Spectrum in Various Countries (in $\mathrm{MHz})^{22}$

\begin{tabular}{|l|l|l|l|}
\hline Country & Current & Pipeline & $\begin{array}{l}\text { Hz/ } \\
\text { Subscriber }\end{array}$ \\
\hline USA & 608 & 55 & 2.1 \\
\hline Germany & 615 & 0 & 6.2 \\
\hline France & 555 & 50 & 9.3 \\
\hline Brazil & 554 & 0 & 2.0 \\
\hline Japan & 500 & 10 & 3.3 \\
\hline Australia & 478 & 230 & 22.8 \\
\hline UK & 353 & 265 & 7.9 \\
\hline China & 227 & 360 & 0.5 \\
\hline India & 221 & 10 & 0.2 \\
\hline
\end{tabular}

Source: Wireless Telecommunications Bureau. Federal Communications Commission.

While spectrum availability is a larger global problem, it is particularly acute in India. According to the COAI Annual Report ${ }^{24}$, operators in India possess significantly smaller amount of spectrum, approximately $31 \mathrm{MHz}$ on average, compared to international standards. This is low even in comparison to other Asian countries, such as Bangladesh (37.4 MHz) and Malaysia $(75 \mathrm{MHz})$.

What is notable from Table 5 is the near absence of a pipeline for future growth of spectrum in India. Despite having extremely low levels of licensed spectrum, there is no effort to catch

\footnotetext{
${ }^{22}$ Wireless Telecommunications Bureau. (2013, February 26). White Paper: The Mobile Broadband Spectrum Challenge: International Comparisons, p. 2. Office of Engineering and Technology. Federal Communications Commission. file:///C:/Users/HP/Downloads/DOC-318485A1.pdf

${ }^{23}$ Cellular Operators Association of India. Annual Report 2015- 16.

${ }^{24}$ Ibid
} 


\section{SOCIAL SCIENCES IN THE 21ST CENTURY}

up. This is in stark contrast to China which is at a comparably low level of spectrum availability as India, but has a significant pipeline. The advanced economies too have serious expansion plans, despite higher spectrum availability today. One measure of spectrum capacity in a country is the amount of spectrum per subscriber. As Table 5 highlights, India has very low capacity at $0.2 \mathrm{~Hz}$ per subscriber.

\subsubsection{Unreasonably High Spectrum Costs}

Spectrum cost in India is one of the highest in the world. Price of spectrum in India runs around " 25 times costlier than the countries such as U.S., France, Singapore, Germany, Spain and Sweden." ${ }^{25}$ By issuing spectrum licenses to Network Operators for 20 years, government policies force them to bear heavy network roll-out costs without providing them sufficient time to earn revenue from the capex and opex costs.

Table 6: Spectrum Price in Various Bands in India ${ }^{26}$

\begin{tabular}{|l|l|l|l|l|l|l|l|l|}
\hline & $\mathbf{7 0 0} \mathbf{M H z}$ & $\begin{array}{l}\mathbf{8 0 0} \\
\mathbf{M H z}\end{array}$ & $\begin{array}{l}\text { 900MH } \\
\mathbf{z}\end{array}$ & $\begin{array}{l}\mathbf{1 8 0 0} \\
\mathbf{M H z}\end{array}$ & $\begin{array}{l}\mathbf{2 1 0 0 M} \\
\mathbf{H z}\end{array}$ & $\begin{array}{l}\mathbf{2 3 0 0 M} \\
\mathbf{H z}\end{array}$ & $\begin{array}{l}\mathbf{2 5 0 0 M} \\
\mathbf{H z}\end{array}$ & Total \\
\hline $\begin{array}{l}\text { Pricing } \\
\text { (in Cr) }\end{array}$ & 57,425 & 29,095 & 45,583 & 14,365 & 18,730 & 16,340 & 16,340 & $\begin{array}{l}1,97,8 \\
78\end{array}$ \\
\hline
\end{tabular}

Source: COAI Annual Report 2015-16

India faces another big challenge from high telecommunications costs. According to the Herfindahl-Hirschman Index (HHI) ${ }^{27}$, India ranks lowest in market concentration at $0.06^{28}$.

Figure 2: Herfindahl-Hirschman Index $(\mathrm{HHI})^{29}$

\footnotetext{
${ }^{25}$ Gary Kim. $2000 \mathrm{MHz}$ of India Mobile Spectrum up for Auction in 2016. http://spectrumfutures.org/2000-mhzof-india-mobile-spectrum-up-for-auction-in-2016/

${ }^{26}$ Cellular Operators Association of India, COAI Annual Report 2015-16, at 14

${ }^{27}$ Measure of Market Concentration and indicates Competition. HHI Index below 0.01 indicates a highly competitive index, between 0.01- 0.15 depicts unconcentrated index, between 0.15- 0.25 depicts moderate concentration and above 0.25 indicates moderate concentration. It is calculated over Subscriber Market Share 28 The World Bank. TCdata360. HH Market Concentration Index. https://tcdata360.worldbank.org/indicators/hh.mkt?indicator=2370\&viz=line chart\&years=1988,2015\#table$\underline{\text { link. }}$. ${ }^{29}$ Ibid.
} 


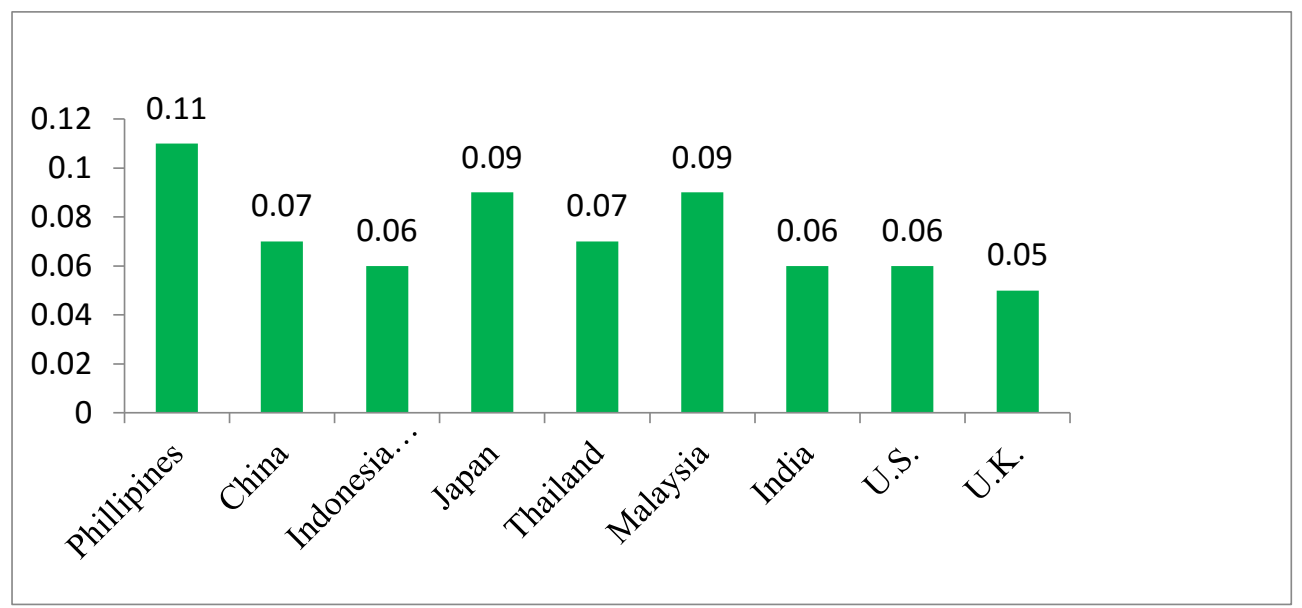

Source: The World Bank, TCdata360, HH Market Concentration Index

The low market concentration is the result of high competition, low tariffs and less revenue. The Average Revenue per Minute for an outgoing call in India is 0.05 INR only ${ }^{30}$. This is probably the reason why Indian consumers report one of the highest average minutes of usage per subscriber per month, at 785 minutes $^{31}$ while the Average Revenue Per User amounts to only Rs $101.65^{32}$ which is quite low as per global statistics.

While low tariffs and high usage reflect high number of subscribers, the cost structure in the Indian wireless mobile communications industry predicts that these benefits will be short lived. With roadblocks in convergence of networks and inadequate spectrum, there is likely to be a serious plunge in quality of wireless mobile services in India.

From 2010 to 2021 the Indian government has earned around INR 4, 34,015 crores through seven spectrum auctions. However, the high cost of spectrum in India has led to a digital divide between urban and rural India thereby affecting the wireless mobile penetration in the country as the operators are reluctant to invest in network deployment resulting in underutilization as well as misutilization of the valuable spectrum.

Figure 3: Income from Spectrum Auctions (INR Crore) $)^{33}$

\footnotetext{
${ }^{30}$ Supra 3 at 58.

${ }^{31}$ Ibid.

${ }^{32}$ Ibid.

${ }^{33}$ Supra 7 at 19.
} 


\section{Income from Spectrum Auctions (INR Crore) 434,015}

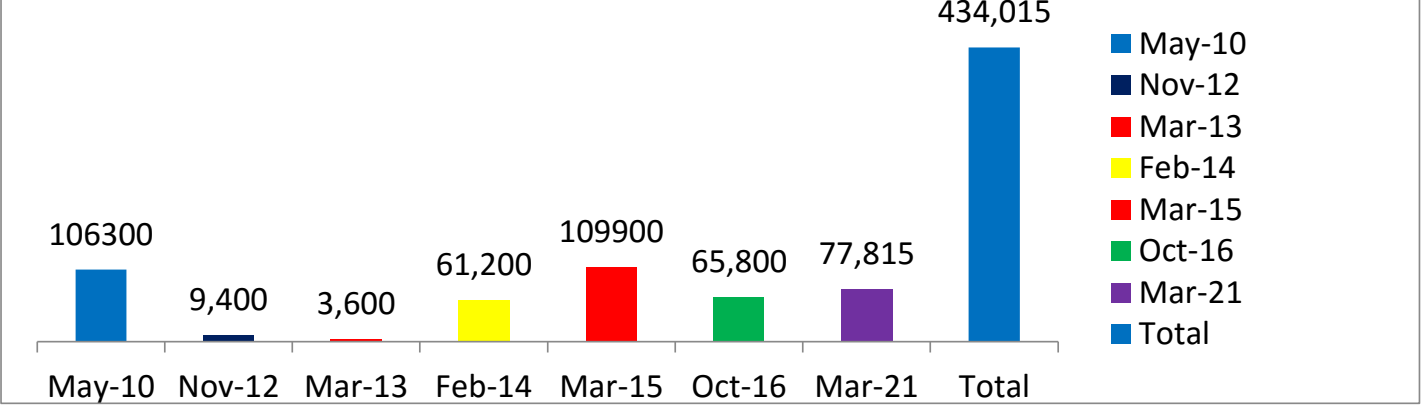

Source: World Bank Report 2015

In a highly competitive telecom market such as India, the Regulatory body is facing a challenge in creating harmony between the Network Operators who wants to generate revenue while continuing to invest in infrastructure and technology and the public sector's interest in earning revenue for the Government through spectrum auctions. High spectrum costs and unreasonably exorbitant penalties have reduced the profit-earning capacity of the wireless network operators thereby restraining their investment ability. In order to survive the cut-throat competition in spectrum auctions, the Operators bid aggressively to acquire heavily- priced spectrum through financial assistance from banks. The Operators have come under huge debts and therefore are reluctant to invest in infrastructure in rural areas. Figure 4 shows that the Indian telecom sector is under a huge debt of INR 7.64 Lakh Crore in the Financial year 2018$19^{34}$.

Figure 4: Debt of Telecom Industry (in '000 Cr) ${ }^{35}$

Figure 4: Debt of Telecom Industry (in ' $000 \mathrm{Cr}$ )

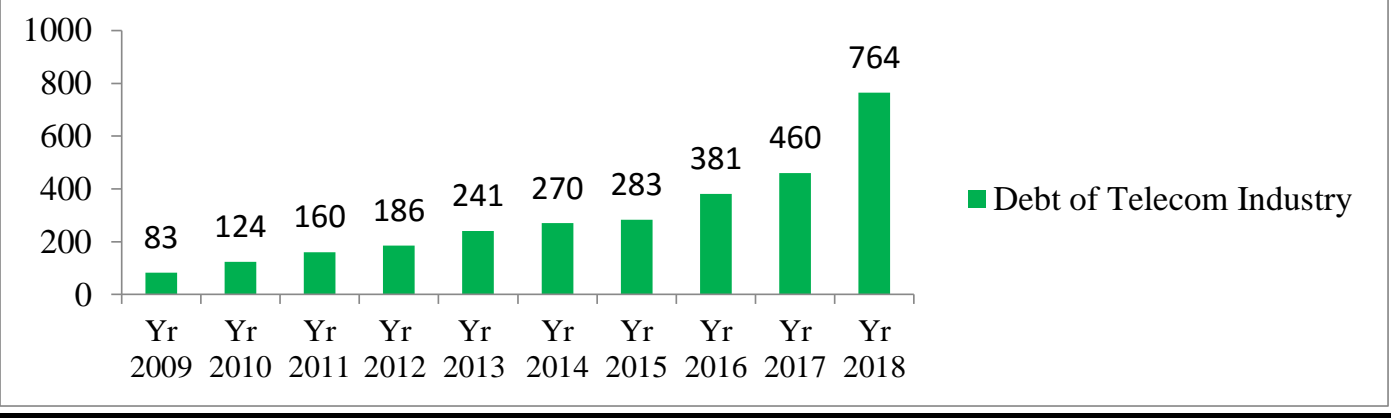

Source: KPMG and ASSOCHAM India's Joint Study on “Accelerating Growth and Ease of Doing Business: Telecommunications

\footnotetext{
${ }^{34}$ Cellular Operator Association of India. (2020). Annual Report 2018- 19- "5G in India: When and How?” p. 5, https://www.coai.com/sites/default/files/COAI\%20Annual\%20Report_2018-19.pdf

${ }^{35}$ KPMG and ASSOCHAM India's Joint Study on "Accelerating Growth and Ease of Doing Business: Telecommunications. August 2017. https://assets.kpmg/content/dam/kpmg/in/pdf/2017/08/Acceleratinggrowth.PDF.
} 


\section{SOCIAL SCIENCES IN THE 21ST CENTURY}

The telecom sector in India also pays huge taxes and levies which amount to 30 percent of revenues in the sector, which is significantly higher than most other emerging economies. Table: 7 shows various taxes and levies charged from Wireless Telecom Service Providers in India and its neighbouring countries.

Table 7: Taxes and Levies in Telecom Sector in India and its Neighbouring Countries ${ }^{36}$

\begin{tabular}{|c|c|c|c|c|c|c|}
\hline $\begin{array}{l}\text { Regulatory } \\
\text { Charges }\end{array}$ & Pakistan & Sri Lanka & China & Malaysia & Bangladesh & India \\
\hline $\begin{array}{l}\text { Service } \\
\text { Tax, GST }\end{array}$ & $\begin{array}{l}18-\quad 19.5 \% \\
{ }^{37}(\text { Sales } \\
\text { Tax) }\end{array}$ & $\begin{array}{l}25.51 \% \\
\text { Telecom } \\
\text { Levy }^{38} \text { (VAT + } \\
\text { MSL }^{39}+ \\
\left.\mathrm{NBT}^{40}+\mathrm{ECL}^{41}\right)\end{array}$ & $\begin{array}{c}11 \% \\
(\mathrm{VAT})\end{array}$ & $6 \%$ (GST) & $\begin{array}{l}19.45 \% \\
\text { (Supplementary } \\
\text { duty+VAT+ } \\
\text { Surcharge) }\end{array}$ & $\begin{array}{l}14 \% \\
\text { (Service } \\
\text { Tax) }+0.5 \% \\
\text { (Swachh } \\
\text { Bharat } \\
\text { cess) + } \\
0.5 \% \text { Krishi } \\
\text { Kalyan } \\
\text { Cess }^{42}\end{array}$ \\
\hline $\begin{array}{l}\text { License } \\
\text { Fee }\end{array}$ & $\begin{array}{l}0.5 \% \mathrm{LF}+ \\
0.5 \% \mathrm{R} \& \mathrm{D}\end{array}$ & $2.04 \%$ & - & $0.5 \%$ & $\begin{array}{l}\text { 5.5\% AGR + } \\
\text { BDT 50mn } \\
\text { (per 2G \&3G } \\
\text { license }\end{array}$ & $8 \%$ \\
\hline SUC & $\begin{array}{l}\text { Cost } \\
\text { recovery }\end{array}$ & - & - & - & - & $2-6 \%$ \\
\hline USO Fund & $\begin{array}{ll}1.5 \% & \text { of } \\
\text { gross } & \\
\text { revenue } & \end{array}$ & - & - & $\begin{array}{l}6 \% \text { of } \\
\text { weighted } \\
\text { net } \\
\text { revenue }\end{array}$ & $1 \%$ of AGR & $\begin{array}{l}5 \% \\
\text { included in } \\
\text { license fee }\end{array}$ \\
\hline $\begin{array}{l}\text { Other } \\
\text { Taxes }\end{array}$ & $\begin{array}{l}\text { Sales tax of } \\
\text { PKR } 250 \text { on } \\
\text { new r or } \\
\text { replacement } \\
\text { SIM }\end{array}$ & $\begin{array}{l}\text { LKR 3/Min } \\
\text { IDD Levy }\end{array}$ & - & - & $\begin{array}{lll}\text { SIM Tax of } \\
\text { BDT } 100 \text { on } \\
\text { New } & \text { or } \\
\text { Replacement } \\
\text { SIM }\end{array}$ & - \\
\hline
\end{tabular}

\footnotetext{
${ }^{36}$ Supra 28 at 40

37 Varies across province

${ }^{38}$ For voice / SMS / VAS, only $10.2 \%$ for data related services

${ }^{39}$ Mobile \& fixed subscribers levy

${ }^{40}$ Nation Building Tax levied in various sectors

${ }^{41}$ Environment conservation levy applicable to multiple sectors;

${ }^{42}$ Effective from June 1, 2016

${ }^{43}$ Levy on international voice and video calls
} 


\begin{tabular}{|l|l|l|l|l|l|c|}
\hline $\begin{array}{l}\text { Telecom } \\
\text { Levy }\end{array}$ & $\begin{array}{l}20.5 \%-22 \% \\
+\quad \text { Cost } \\
\text { recovery+ } \\
\text { SIM Tax }\end{array}$ & $\begin{array}{l}27.55 \%+\text { IDD } \\
\text { Levy }\end{array}$ & $11 \%$ & $12.5 \%$ & $\begin{array}{l}25.95 \%+\text { BDT } \\
50 \text { Min per }\end{array}$ & $25-29 \%$ \\
License + SIM & \\
Tax & \\
\hline $\begin{array}{l}\text { Telecom } \\
\text { Specific } \\
\text { Levy }\end{array}$ & $\begin{array}{l}2.5 \%+\text { Cost } \\
\text { Recovery }+ \\
\text { SIM Tax }\end{array}$ & $\begin{array}{l}12.04 \% 44+ \\
\text { IDD Levy }\end{array}$ & - & $0.5 \%$ & $\begin{array}{l}6.5 \%+\text { BDT 50 } \\
\text { Min Per } \\
\text { License+ SIM } \\
\text { Tax }\end{array}$ & $10-14 \%$ \\
\hline
\end{tabular}

Source: The World Bank. TCdata360. HH Market Concentration Index.

Despite this situation, total Foreign Direct Investment in Telecommunications sector as in March 2019 has been around USD 3.28 million. ${ }^{45}$ The impact of these high costs has also affected the quality of service which is evident from the growing number of call- drops and interruptions. There is a need for Telecom Operators to find innovative methods of passive network sharing and to further invest in cellular infrastructure such as mobile towers.

\subsubsection{Inefficient Spectrum Auctions}

Inefficient spectrum allocation or utilization can aggravate network congestion. This is not just a nuisance: it has an economic cost. Smooth access to information and quick transactions accelerates economic productivity of a country whereas obstructed communications lead to inefficiency. To use an analogy, a very bad road between two cities might not block the transfer of goods between the two, but it may lead to costly delays. Network congestion also reduces Consumer Surplus (CS): demand is then constrained by capacity rather than just by price. The cost of inefficient spectrum allocation in India is in the order of $\$ 3.6$ billion per annum on foregone Economic Surplus ${ }^{46}$.

A successful spectrum auction must fulfill the following two objectives:

i. Efficient spectrum auction that enables optimal use of spectrum,

ii. Earn maximum government revenue

However, an analysis of spectrum planning and management procedure of India reveals that so far, the focus has been more on the second objective only. The 2G Scam in 2008 followed by two failed auctions in 2012 and 2013 raises a serious question on the spectrum planning and management in India.

\footnotetext{
44 Telecom levy includes $10 \%$ MSL; 8. $0.5 \%$ or RM 50,000 whichever is higher

${ }^{45}$ Department of Industrial Policy and Promotion. Quarterly Factsheet on Foreign Direct Investment January March 2019, Ministry of Commerce and Industry. Government of India. https://dipp.gov.in/sites/default/files/FDI_Factsheet_27May2019.pdf.

${ }^{46}$ Global System for Mobile Association. (2014, October). The Cost of Spectrum Auction Distortions. 3. https://www.gsma.com/spectrum/wp-content/uploads/2014/11/The-Cost-of-Spectrum-Auction-Distortions.GSMA-Coleago-report.-Nov14.pdf.
} 
The Hon'ble Supreme Court of India through its judgment in the 2G Case, dated 2nd February 2012, quashed the licenses granted on or after 10th January 2008 and ordered to issue fresh licenses by auctions. After examining the government's decisions, the Indian Supreme Court condemned them as "arbitrary," "unconstitutional," and "illegal." Hon'ble Supreme Court had a major effect on spectrum allotment procedure. Since then, six spectrum auctions have been held, two of which had failed (November 2012 and March 2013 Auctions) as there was no bidder due to exorbitantly high spectrum costs. These spectrum auctions have contributed to unreasonably high spectrum costs by creating an artificial scarcity of spectrum.

3.1.4.1 First 3G Spectrum Auction (In 2010)- India organized 3G spectrum auctions that generated 677.1 billion rupees from bidders. Among the successful firms were Bharti Airtel, which spent 122.95 billion rupees on 13 circles, Vodafone, which spent 116.18 billion rupees in nine circles, Reliance Communications ( 85.85 billion rupees) on 13 regions, Aircel (65 billion rupees) on 13 circles, and Idea Cellular (57.69 billion) on 11 areas $^{48}$.

But wireless operators complained that the government auction raised prices to unreasonable levels and forced them to take on high debt levels. According to Bharti Airtel, "the auction format and severe spectrum shortage along with ensuing policy uncertainty drove the prices beyond reasonable levels. As a result, we could not achieve our objective of a panIndia $3 \mathrm{G}$ footprint in this round ${ }^{49}$."

Later auctions also sold spectrum at unreasonably high prices. According to a report by Coleago Consulting, 15 percent of the $850 \mathrm{MHz}$ and $1800 \mathrm{MHz}$ bandwidth auctioned between 2012 and 2014 was "unutilized," despite pressing industry needs. The auctions suffered from "high reserve prices, technology bias, regulatory uncertainty and historic spectrum fragmentation. ${ }^{50}$

3.1.4.2 Second Spectrum Auction (November 2012)- Following the directions of the Hon'ble Supreme Court in 2G Case, the first auction was held for spectrum in the $1800 \mathrm{MHz}$ and 800 $\mathrm{MHz}$ bands in November 2012. Due to high reserve price of spectrum, there was no bidder for the spectrum in the $800 \mathrm{MHz}$ band. However, in $1800 \mathrm{MHz}$, except in the Licensed Service Areas of Delhi, Mumbai, Karnataka and Rajasthan, some spectrum was sold in all the other service areas and $40 \%$ of spectrum remained unsold ${ }^{51}$.

3.1.4.3 Third Auction (March 2013)- In the 2013 spectrum auction, the Government planned to auction $50 \mathrm{MHz}$ of airwaves in the $1800 \mathrm{MHz}$ band and $76.25 \mathrm{MHz}$ of spectrum in the

\footnotetext{
${ }^{47}$ Centre for Public Interest Litigation \& Others v. Union of India \& Others. Writ Petition (Civil) No. 423 of 2010. http://www.indiaenvironmentportal.org.in/files/2G\%20spectrum.pdf

${ }^{48}$ Nicole McCormick. (2010, May 20). India’s 3G Auction Raises \$15b. TELECOMASIA.NET. http://www.telecomasia.net/content/indias-3g-auction-raises-15b.

${ }^{49}$ Ibid

50 Supra 46.

${ }^{51}$ Telecom Regulatory Authority of India. Consultation Paper No. 06/2015, (2015, November 26). Consultation Paper on Valuation and Reserve Price of Spectrum in 700, 800, 900, 1800, 2100, 2300 and 2500 MHz Bands. 4.
} 
$800 \mathrm{MHz}$ band. ${ }^{52}$ The Government put CDMA spectrum worth ₹ 64 billion up for auction ${ }^{53}$ and fixed the price of $900 \mathrm{MHz}$, two times higher than $1800 \mathrm{MHz}^{54}$

No Operator tendered bids for spectrum in $1800 \mathrm{MHz}$ and $900 \mathrm{MHz}$ bands due to high reserve prices, and the sole bidder in the auction was Sistema Shyam Teleservices Limited (SSTL), under the brand name MTS India who bid for spectrum in the $800 \mathrm{MHz}$ band. Around $70 \%$ of Spectrum in $850 \mathrm{MHz}$ Band remained unsold.

3.1.4.4 Fourth Auction (February 2014) - In 2014, the Department of Telecom (DoT) auctioned 2G spectrum in $900 \mathrm{MHz}$ and $1800 \mathrm{MHz}$ Bands. The Government earned 612 billion INR from the spectrum auction. The most expensive telecom circle in both $900 \&$ $1800 \mathrm{MHz}$ Bands $^{55}$ was Delhi at a price of 7409.6 million INR and 728 million INR per operator. Delhi and Mumbai together accounted for $57 \%$ of the total bids. ${ }^{56}$ From these figures, it can be easily assessed that irrational spectrum pricing is one of the biggest reason in creating a digital divide between urban and rural India as after acquiring expensive spectrum, Operators prefer to invest in Metropolitan and Class A circles, for which they already have spectrum and avoid investing in spectrum for rural parts of India in order to cut down on network roll-out costs.

In India, three consecutive failures in fully allocating the available $1800 \mathrm{MHz}$ spectrum between 2012 and 2014 has decelerated the speed of network deployment. Spectrum policy in India is similar to a descending 'Dutch auction" ${ }^{57}$, whereby the reserve price is reduced gradually over repeated iterations. But each failed attempt of efficient allocation of spectrum postpones the economic benefits associated with the commercial use of this resource. This problem could have been avoided if spectrum could have been priced reasonably, allowing the market to determine the final prices paid.

3.1.4.5 Fifth Auction (March 2015) - In 2015, the government auctioned spectrum in the 800, 900, 1800, and $2100 \mathrm{MHz}$ Bands which are suitable for mobile broadband services. Cellular Operators bid aggressively for these Bands in the auction because acquiring spectrum in these Bands was crucial for their future roll-out plans. In the case of Aditya Birla Group's Idea, the company's "900 MHz spectrum in nine circles accounts for a whopping 72 percent of its revenue. ${ }^{58 "}$ With so much of its revenue dependent on a relatively small number of geographic areas, it put the

\footnotetext{
52 Sounak Mitra. Telecom spectrum auction application process ends today. Business Standard. http://www.business-standard.com/article/companies/telecom-spectrum-auction-application-process-ends-today113022500105_1.html

${ }^{53}$ Press Trust of India. (2013, March 10). Second round of spectrum auction from tomorrow, SSTL lone bidder, THE ECONOMIC TIMES. http://articles.economictimes.indiatimes.com/2013-0310/news/37598162_1_spectrum-auction-bwa-spectrum-megahertz-spectrum. 
company (and many other Operators) in a vulnerable position as it moved into the future. In the $1800 \mathrm{MHz}$ band only three circles had a minimum of $5 \mathrm{MHz}$ of contiguous spectrum as a result this band was allocated to a limited extent only.

3.1.4.6 Sixth Auction (October 2016)- The latest auction of 2016 is a staunch example of poor spectrum planning and short-sighted approach in deciding reserve price before auctions in India wherein $40 \%$ of the airwaves remained unsold due to unrealistically high spectrum pricing.

A total of $2354.55 \mathrm{MHz}^{59}$ of spectrum ranging across the 7 bands of $700 \mathrm{MHz}, 850 \mathrm{MHz}$, $900 \mathrm{MHz}, 1800 \mathrm{MHz}, 2100 \mathrm{MHz}, 2300 \mathrm{MHz}$ and $2500 \mathrm{MHz}$ was put up for sale across 22 different circles. This was the first auction in India in which $700 \mathrm{MHz}$ band spectrum was put on auction despite repeated requests from cellular operators for postponing the auction of this Band. Due to high pricing, no one bid for $700 \mathrm{MHz}$ Band, offered for the first time in an auction. It was auctioned at a reserve or base price of Rs 11,485 crore per MHz.

For buying pan-India $5 \mathrm{MHz}$ spectrum in this band, a telecom operator would have to pay a minimum of Rs 57,425 crore if no counter bids came in. This band alone had the potential to fetch bids worth over Rs 4 lakh crore. The telecom operators, who have a debt of Rs 3.80 lakh crore $^{60}$, stayed away from $700 \mathrm{MHz}$ spectrum and mostly submitted bids in $2500 \mathrm{MHz}, 2300$ $\mathrm{MHz}, 800 \mathrm{MHz}$ and $1800 \mathrm{MHz}$ bands.

3.1.4.7 Seventh Auction (March 2021)- The recent 4G spectrum auction was also unsuccessful as only 37 percent of spectrum was sold. The $700 \mathrm{MHz}$ Band which is considered to be the most crucial band for 5G technology also remained unsold due to its high price. The spectrum acquired by the operators in this auction will definitely augment $4 \mathrm{G}$ penetration in India but India is way behind other countries in adopting 5G technology and in order to fulfil the objectives set- out in the National Digital Communications Policy 2018, India has to create an ecosystem for faster deployment of advanced technologies.

The above analysis of spectrum auctions in India clearly reveals that the government has concentrated more on short term maximization of profits through auctions, penalties, taxes etc. at the cost of long- term economic as well as technological growth of the sector. Unreasonably high spectrum prices overwhelmingly increase the fixed cost for network operators thereby becoming a hindrance in infrastructure investments which eventually leads to poor quality of service which adversely affects the end- users. Government policies must be futuristic that allows smooth adoption of new technologies and developments thereby enabling accelerated growth of the sector and consumer satisfaction.

\subsection{Recommendations For Future Action:}

A comparative analysis of Indian telecom sector with other developed countries as discussed in preceding paras reveal investments in telecom infrastructure and futuristic

59 Pawan Bali. (2016, October 7). Higher Prices Fail Spectrum Auctions. DECCAN CHRONICLE. http://www.deccanchronicle.com/business/in-other-news/071016/higher-prices-fail-spectrum-auction.html ${ }^{60}$ Ibid. 
spectrum policies are strong enablers of economic growth. Clear policies, affordable devices, harmonized spectrum bands, convergence of networks, efficient spectrum pricing and planning have a huge potential to drive the overall economy. According to a McKinsey Global Institute Study, with efficient spectrum planning and execution, India could boost Mobile Internet Penetration from its current $8-10 \%$ up to $50-60 \%$ by $2025^{61}$. The report further claims that with the adoption of other technological advancements, the country's Gross National Product can rise from $\$ 550$ Billion to $\$ 1$ Trillion by $2025 .{ }^{62}$ These objectives can only be achieved when the Government does not kill the goose that lays the golden eggs due to its greed to earn short- term revenues through high pricing, penalties and taxes.

\subsubsection{Efficient spectrum planning before auctions-}

The long lead time needed for the introduction of new services and new spectrum bands requires long-term planning. India should start planning now for its spectrum needs in 2020-2025. At WRC-15 additional spectrum bands were identified for mobile broadband, particularly the $\mathrm{L}$ band $(1427-1518 \mathrm{MHz})$, part of the $\mathrm{C}$ band $(3.3-3.4 \mathrm{GHz}$ ) and supporting sub-700 MHz band (470-698 MHz). The Indian government should now commit to these bands at the national level and prepare a roadmap for the largely unused bands. The National Digital Communications Policy- 2018 should be revised to include newer bands for $5 \mathrm{G}$ technology in India. At the same time, use of any unlicensed services in the 470-698 MHz band should not compromise licensing the band for mobile broadband and opportunities for mobile operators to introduce new services envisaged over $5 \mathrm{G}$.

\subsubsection{There should be a Time- Table for future Spectrum Auctions-}

Operators should be pre- informed about the availability of spectrum in all the bands well in advance before the auctions. This step would enable them to take bidding decisions based on facts and information and not desperation.

\subsubsection{Harmonization of Spectrum at National as well as International level-}

Harmonization of spectrum at International, National and Regional level is imperative to avoid wastage of spectrum and can further free up a good amount of spectrum. For example, in India, Telecom Service Providers have been allotted different spectrum frequencies in the same band for cities within a circle for which they have obtained a license. This raises network roll- out costs and leads to spectrum misutilization. Similarly, when $1800 \mathrm{MHz}$ and $2100 \mathrm{MHz}$ bands were the most popular bands globally for $4 \mathrm{G}$ and $3 \mathrm{G}$ respectively, in India Operators had been using 2300 $\mathrm{MHz}$ band to deploy LTE technology due to unavailability of contiguous spectrum in the $1800 \mathrm{MHz}$ band resulting in higher network roll- out costs that slowed down the penetration of $4 \mathrm{G}$ in the country. Although the government has successfully harmonised

\footnotetext{
${ }^{61}$ Noshir Kaka Et Al. (2014, October). India's Technology Opportunity: Transforming work, empowering people. McKinsey Global Institute. 5.

${ }^{62}$ Id at 6.
} 
and made available additional spectrum in the $1800 \mathrm{MHz}$ and $2100 \mathrm{MHz}$ bands for the 2016 auctions but new uses of mobile technology will require greater access to spectrum mid- band and mm- wave spectrum for 5G technology.

\subsubsection{Spectrum Trading and Sharing should be encouraged-}

Spectrum band planning should be compatible with the policies related to unified licensing, spectrum sharing and trading which would enable faster penetration of broadband services in India. Clear and transparent policies on spectrum sharing and trading will also allow efficient utilisation of spectrum which is a limited resource.

\subsubsection{Spectrum renewal and Spectrum Usage Charges to be made simple-}

Equally, the government must lower revenue-share-linked spectrum usage charges that were put in place prior to the policy of market-linked spectrum costs discovered through auctions. This will allow the industry to invest precious capital in rolling out networks, benefiting society rather than pouring money behind just acquiring spectrum - a benefit that leads only to short-term gain for the exchequer.

\subsubsection{An Artificial Scarcity of Spectrum should be eliminated to reduce the cost of doing business-}

The cost of spectrum in India is extremely high. This is because of the artificial spectrum scarcity that has been created by putting only very limited spectrum up for auction with much of it remaining with defence and government operators who are immersed in debt and are sitting on unused spectrum. The government must make efforts to free up this spectrum and put it for auction in the near future which would help in meeting up the demands of the telecom service providers

\subsubsection{More spectrum should be made available in MHz bands-}

Operators cannot provide high- speed data services without adequate spectrum. Much of the spectrum in India is with the defence and what is available is fragmented because there are too many players. As a result, the average holding of Indian companies is $31 \mathrm{MHz}$ compared to $50 \mathrm{MHz}$ in western countries ${ }^{63}$. The result of these inadequate holdings is the inefficient use of spectrum by operators with fewer customers on the one hand and congested networks and poor customer experience on the other. Additionally, it results in the need for more towers and more energy - an outcome that is good for no one.

\footnotetext{
${ }^{63}$ BusinessToday.in. (2021, January 25). 5 G Spectrum 'Reasonable' Pricing Critical for Future of Telecom https://www.businesstoday.in/industry/telecom/story/5g-spectrums-reasonable-pricing-critical-for-future-oftelecom-285417-2021-01-25
} 


\subsubsection{Reforming policies and regulations to achieve the objective of 'Digital India'-}

While market dynamics can shift quickly, regulations and policies have failed to catch up with the pace of technological developments and market demands, and this is creating uncertainties and ambiguities that becomes a hindrance in meeting policy objectives which in turn leads to customer dissatisfaction. Cellular operators are subject to regulatory and public policy obligations that other players in the digital ecosystem are not, giving the latter more flexibility and competitive advantage therefore obligations placed on Telecom service providers should be reduced. The current licensing framework therefore needs reforms which are in conformity with technological developments and market demands.

\subsubsection{The cost of doing business be reduced-}

Mobile operators in India are under huge debts due to high spectrum pricing, administrative fees and levies. Quick and successful deployment of networks calls for smooth approval processes and practical tax and fee structures that encourage investments in infrastructure. In the recently concluded auctions in March 2021, the government failed to sell any spectrum in the $700 \mathrm{MHz}$ band. The entire spectrum in this sought-after band went unsold due to an unrealistically high reserve price. This could have a negative impact on investment in next-generation networks at a time when demand for mobile data is growing rapidly. Reserve prices should be set conservatively so as not to undermine the price-discovery function of the auction that is central to the market-based approach to spectrum management The Universal Service Obligation Fund (USOF) levy is also an area that merits review. The current state of mobile coverage in India does not warrant the 5\% USOF levy, particularly compared to universal service rates in other countries. ${ }^{64}$ The state of connectivity in India would be well served by a review of the effectiveness of the USOF in supporting broadband deployment.

\subsubsection{Ease of doing Business be Improved-}

Although the Government has allowed 100\% Foreign Direct Investment in Telecom Sector, yet the foreign investors are reluctant in investing further in India due to delay in policies and uncertain and ambiguous market environment. Furthermore, the process of establishing business in India is highly complicated with multiple windows and taxation compliances, as discussed in preceding paras. The government must provide smooth approval processes. Similarly, introduction of single window clearance will reduce unnecessary administrative costs. In November 2016, the government has issued the Right of Way Policy to enable faster deployment of network that has been welcomed by Telecom Service Providers but regulatory obstacles such as overly restrictive electromagnetic field (EMF) exposure slow the rollout of networks and discourage investment. Updates in 2017 to the World Health Organization's EMF

${ }^{64}$ Global Mobile Suppliers Association. (2013, April). Universal Service Fund Study p.146. 
health risk assessment and the opening of the forthcoming EMF Portal provide an opportunity for India to adopt globally accepted technical standards, removing a barrier to efficient mobile network deployment.

\section{Conclusion}

The Global Economic Prospects Report by World Bank forecasts Indian economy to grow at a rate of 8.3 percent in the Year $2021^{65}$ and despite facing the economic challenges due to the second wave of pandemic, it is likely to be the fastest-growing economy in the world by 2022 according to the United Nations report ${ }^{66}$. The socio-economic landscape of Asia's thirdlargest economy has seen many ups and downs after British rule. The economic growth has accelerated significantly in the last two decades to reach a GDP of USD 3.04 trillion $^{67}$ and the foreign exchange reserves have touched the record high of USD 608 Billion ${ }^{68}$ by June 18, 2021 enabling India to face external shocks. Amidst all these positive developments, there is one factor, i.e., 'Corruption' which is posing a major challenge in the growth and development of the Indian economy. The Corruption Perceptions Index 2020 puts India on the $86^{\text {th }}$ position among 180 countries in the survey ${ }^{69}$.

Trust is a fundamental element while doing business and though India provides a favourable platform, still it ranks 63 amongst 190 countries surveyed in the World Bank's Easeof-Doing Business Report $2020^{70}$ due to unfair business practices in financial dealings, government spending, banking policies, credit policies, tax and trading, etc. prevalent since independence. It is expected that with demonetization and digitalization initiatives by the government, the level of corruption will decelerate in India. Transparency, Accountability and Accessible Information are the three pillars of good governance in any country. Therefore, it is imperative to take significant steps in this direction to put India on a better footing on global platform.

The evolving digital and communication technologies are providing innovative ways to counter corruption faced by the country on a large scale. The government through its Digital India program has set an ambitious goal of addressing these challenges using 5G Technology, ICT (Information and Communications Technology) and SMAC (Social, Mobile, Analytics, Cloud) technologies.

\footnotetext{
${ }^{65}$ Global Economic Prospects, World Bank, June 2021, p. 4 https://openknowledge.worldbank.org/bitstream/handle/10986/35647/9781464816659.pdf

${ }^{66}$ World Economic Situation and Prospects as of mid- 2021. (2021, May 11). p. 3

https://www.un.org/development/desa/dpad/wp-content/uploads/sites/45/publication/WESP2021_UPDATE.pdf

${ }^{67}$ Statistics Times. (2021). GDP of India. https://www.statista.com/statistics/263771/gross-domestic-productgdp-in-india/

68 The Reserve Bank of India. (2021, June 18). Weekly Statistical Supplement https://rbidocs.rbi.org.in/rdocs/Wss/PDFs/2T_18062021C2AB02D74E124275A1720C1883E77980.PDF

${ }^{69}$ Transparency International. (2020). Global Perceptions Index 2020, https://www.transparency.org/en/cpi/2020/index/nzl\#

70 The World Bank. (2020). Doing Business https://www.doingbusiness.org/en/data/exploreeconomies/india
} 


\section{SOCIAL SCIENCES IN THE 21ST CENTURY}

Today, only 'Technology' has the potential to ensure good governance and transparency in any country. With the evolution of wireless mobile communications and broadband penetration in India, Technology has become a powerful instrument to reinforce the 'Era of Truth' (Satyuga). With the introduction of 'Digital India Programme', Technology can lead India from Untruth to Truth, from darkness to light and from Death (corruption) to Immortality thereby achieving the national motto of 'Satyamev Jayate' ("Truth Alone Triumphs") in its true letter and spirit. 


\section{References}

BusinessToday.in. (2021, January 25). 5G Spectrum 'Reasonable' Pricing Critical for Future of Telecom https://www.businesstoday.in/industry/telecom/story/5g-spectrums-reasonablepricing-critical-for-future-of-telecom-285417-2021-01-25

Catherine Haslam. (2016, November 29). A Guide to India's Telecom Market, India Calling Info. http://www.indiacallinginfo.com/india-telecom-circles

Cellular Operator Association of India. (2020). Annual Report 2018- 19- "5G in India: When and How?" p. 5, https://www.coai.com/sites/default/files/COAI\%20Annual\%20Report_2018-19.pdf

Cellular Operators Association of India, COAI Annual Report 2015-16, at 14

Centre for Public Interest Litigation \& Others v. Union of India \& Others. Writ Petition (Civil) No. 423 of 2010.

http://www.indiaenvironmentportal.org.in/files/2G\%20spectrum.pdf

Centre for Strategic and International Studies. (1991, September 19). The New Spectrum Mudwrestle: WARC 1992 and Beyond (Washington D.C.: CSIS International Communications Studies, Symposium, 1992), (p. vi). 
Christine Zhen-Wei Qiang. (2009, November). Mobile Telephony - A Transformational Tool for Growth and Development, PROPARCO'S MAGAZINE, Issue 4 November 2009, at 8. Available: https://blog.private-sector-and-development.com/2009/12/21/mobile-phone-atransformational-tool-for-growth-development/

Department of Industrial Policy and Promotion. Quarterly Factsheet on Foreign Direct Investment January - March 2019, Ministry of Commerce and Industry. Government of India. https://dipp.gov.in/sites/default/files/FDI_Factsheet_27May2019.pdf.

Department of Telecommunications, National Telecom Policy-2012. Ministry of Communications. Government of India. https://dot.gov.in/sites/default/files/NTP06.06.2012-final_0.pdf

Gary Kim. 2000 MHz of India Mobile Spectrum up for Auction in 2016. http://spectrumfutures.org/2000-mhz-of-india-mobile-spectrum-up-for-auction-in-2016/

Global Economic Prospects, World Bank, June 2021, p. 4 https://openknowledge.worldbank.org/bitstream/handle/10986/35647/9781464816659.pdf

Global Mobile Suppliers Association. (2013, April). Universal Service Fund Study p.146.

Global Mobile Suppliers Association. (2021, June 30). Status of the LTE Ecosystem p. 5. https://gsacom.com/reports/ 
Global System for Mobile Association. (2014, October). The Cost of Spectrum Auction Distortions. 3. https://www.gsma.com/spectrum/wp-content/uploads/2014/11/The-Cost-of$\underline{\text { Spectrum-Auction-Distortions.-GSMA-Coleago-report.-Nov14.pdf. }}$

Invest India- National Investment Promotion and Facilitation Agency. (2021, June). Telecom Sector https://www.investindia.gov.in/sector/telecom

KPMG and ASSOCHAM India's Joint Study on “Accelerating Growth and Ease of Doing Business: Telecommunications. August 2017.

https://assets.kpmg/content/dam/kpmg/in/pdf/2017/08/Accelerating-growth.PDF.

Martin Cave et al. (2007). Essentials of Modern Spectrum Management. Cambridge University Press.

Measure of Market Concentration and indicates Competition. HHI Index below 0.01 indicates a highly competitive index, between 0.01 - 0.15 depicts unconcentrated index, between $0.15-0.25$ depicts moderate concentration and above 0.25 indicates moderate concentration. It is calculated over Subscriber Market Share

Michael Minges. (2015). Exploring the Relationship between Broadband and Economic Growth. World Bank. https://documents1.worldbank.org/curated/en/178701467988875888/pdf/102955-WPBox394845B-PUBLIC-WDR16-BP-Exploring-the-Relationship-between-Broadband-andEconomic-Growth-Minges.pdf 
Nevin John. Paying the Price. Business Today.

http://www.businesstoday.in/magazine/focus/spectrum-bids-to-add-to-telecos-debtburden-cause-high-tariff/story/217164.html.

Nicole McCormick. (2010, May 20). India’s 3G Auction Raises \$15b.

TELECOMASIA.NET. http://www.telecomasia.net/content/indias-3g-auction-raises-15b.

Nikhil Pahwa, Medianama, India's 20142 G Auction Ends: Operator \& Circle Results, http://www.medianama.com/2014/02/223-india-2g-auction-2014-results-operator-circlewinners/

Noshir Kaka Et Al. (2014, October). India's Technology Opportunity: Transforming work, empowering people. McKinsey Global Institute. 5.

Pawan Bali. (2016, October 7). Higher Prices Fail Spectrum Auctions. DECCAN CHRONICLE. http://www.deccanchronicle.com/business/in-other-news/071016/higherprices-fail-spectrum-auction.html

Press Trust of India. (2013, March 10). Second round of spectrum auction from tomorrow, SSTL lone bidder, THE ECONOMIC TIMES.

http://articles.economictimes.indiatimes.com/2013-03-10/news/37598162_1_spectrumauction-bwa-spectrum-megahertz-spectrum.

Sounak Mitra. Telecom spectrum auction application process ends today. Business Standard. http://www.business-standard.com/article/companies/telecom-spectrum-auctionapplication-process-ends-today-113022500105_1.html 
Statistics Times. (2021). GDP of India. https://www.statista.com/statistics/263771/grossdomestic-product-gdp-in-india/

Sunny Sen. Searching for a Voice. Business

Today.http://www.businesstoday.in/magazine/focus/why-reliance-jio-is-biddingaggressively-for-2g-spectrum/story/203172.html.

Supra 3 at 24. Total Wireless subscriptions by Oct. 2020 is $1,153.77$ million whereas wireline subscription was 20.05 million.

Telecom Regulatory Authority of India. (2005, March). Performance Indicator Report October-December 2003 http://www.trai.gov.in/WriteReadData/PIRReport/Documents/Report\%20QE\%20Dec-03\%203rd\%20march\%202004.pdf

Telecom Regulatory Authority of India. Consultation Paper No. 06/2015, (2015, November 26). Consultation Paper on Valuation and Reserve Price of Spectrum in 700, 800, 900, 1800, 2100, 2300 and $2500 \mathrm{MHz}$ Bands. 4.

Telecom Regulatory Authority of India. Government of India. (2005, May 13).

Recommendations on Spectrum related Issues p. 22.

https://www.trai.gov.in/sites/default/files/spectrumreco.pdf

Telecom Regulatory Authority of India. Government of India. (2005, March). Performance Indicator Report October- December 2004 http://www.trai.gov.in/WriteReadData/PIRReport/Documents/report22mar05.pdf 
The Reserve Bank of India. (2021, June 18). Weekly Statistical Supplement https://rbidocs.rbi.org.in/rdocs/Wss/PDFs/2T_18062021C2AB02D74E124275A1720C188 $\underline{\text { 3E77980.PDF }}$

The Telecom Regulatory Authority of India. (2021, April). The Indian Telecom Services Performance Indicators Oct- Dec 2020 p. 13

https://trai.gov.in/sites/default/files/QPIR_27042021_0.pdf

The World Bank. (2020). Doing Business

https://www.doingbusiness.org/en/data/exploreeconomies/india

The World Bank. TCdata360. HH Market Concentration Index.

https://tcdata360.worldbank.org/indicators/hh.mkt?indicator=2370\&viz=line_chart\&years $=1988,2015 \#$ table-link.

Transparency International. (2020). Global Perceptions Index 2020, https://www.transparency.org/en/cpi/2020/index/nzl\#

Wireless Planning and Coordination Wing. (2011, September). National Frequency Allocation Plan 2011 p. 194. Department of Telecommunications. Ministry of Communications and Information Technology. Government of India. http://www.wpc.gov.in/WriteReadData/Orders/spectrum\%20holding\%20as\%20on\%20Jan uary\%2031_\%202015.pdf 
$3^{\text {rd }}$ International Conference on

SOCIAL SCIENCES IN THE 21ST CENTURY

Wireless Planning and Coordination Wing. (2015, January 31). Spectrum Holding of Telecom

Service Providers. https://www.coai.com/sites/default/files/National-Frequency-

Allocation-Plan-NFAP-2011_0_0_0.pdf.

Wireless Telecommunications Bureau. (2013, February 26). White Paper: The Mobile

Broadband Spectrum Challenge: International Comparisons, p. 2. Office of Engineering and Technology. Federal Communications Commission.

file:///C:/Users/HP/Downloads/DOC-318485A1.pdf

World Economic Situation and Prospects as of mid- 2021. (2021, May 11). p. 3

https://www.un.org/development/desa/dpad/wp-

content/uploads/sites/45/publication/WESP2021_UPDATE.pdf 


\section{SOCIAL SCIENCES IN THE 21ST CENTURY}

\section{Table 1}

Wireless Cellular Mobile Communication Services have been allotted the following bands in India

\begin{tabular}{|c|c|c|c|}
\hline Band & Band Name & Technology & $\begin{array}{l}\text { Frequency Allotted (in } \\
\text { MHz) }\end{array}$ \\
\hline $800 \mathrm{MHz}$ & CDMA & 2G/LTE- FDD & 824- 844/ 869- 889 \\
\hline $900 \mathrm{MHz}$ & $\begin{array}{c}\text { GSM/ n8- 5G } \\
\text { NR Band }\end{array}$ & $\begin{array}{c}\text { 2G/UMTS/ } \\
\text { HSPA/ } \\
\text { WCDMA/ LTE } \\
\text { (4G)/ 5G }\end{array}$ & 890- 915/ 935- 960 \\
\hline $1800 \mathrm{MHz}$ & $\begin{array}{c}\text { GSM/ 3GPP } \\
\text { Band B3 }\end{array}$ & 2G/LTE- FDD & $1710-1785 / 1805-1880$ \\
\hline $2100 \mathrm{MHz}$ & $\begin{array}{l}\text { 3GPP Band } \\
\text { B1/ UMTS }\end{array}$ & $\begin{array}{l}\operatorname{UMTS}(3 \mathrm{G}) / \\
\operatorname{LTE}(4 \mathrm{G})\end{array}$ & $1920-1980 / 2110-2170$ \\
\hline $2300 \mathrm{MHz}$ & $2.3 \mathrm{GHz}$ Band & $\begin{array}{l}\text { TD- LTE }(4 G) / \\
5 G\end{array}$ & 2300- 2400 \\
\hline $2500 \mathrm{MHz}$ & 3GPP B41 & TD- LTE (4G) & $2500-2690$ \\
\hline
\end{tabular}

Source: Wireless Planning and Coordination Wing. Department of Telecommunications. Government of India. 
$3^{\text {rd }}$ International Conference on

SOCIAL SCIENCES IN THE 21ST CENTURY

Table 2

Frequencies allotted to Airtel in the $1800 \mathrm{MHz}$ Band in Delhi in Spectrum Auction 2015
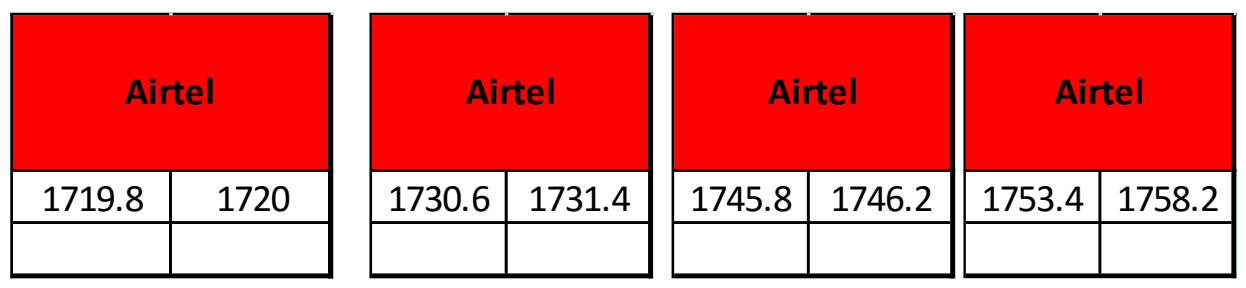

Table 3

Frequencies allotted to Airtel \& Vodafone in the $900 \mathrm{MHz}$ Band in Kolkata

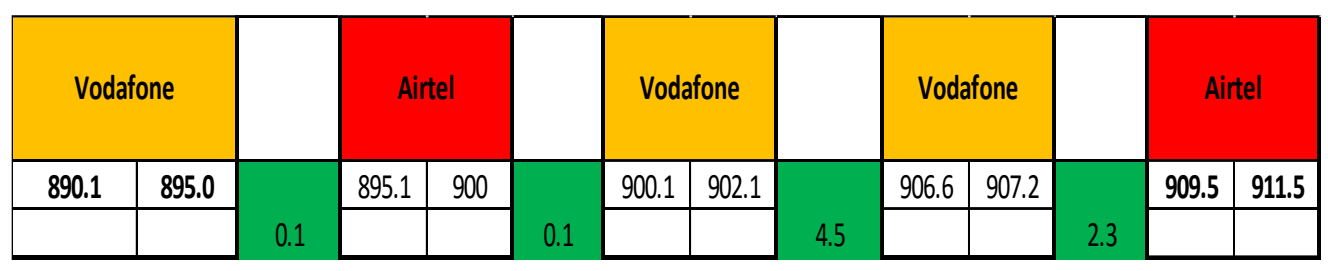

Table 4

Spectrum held by Airtel in the $900 \mathrm{MHz}, 1800 \mathrm{MHz}, 2100 \mathrm{MHz}$ and $2300 \mathrm{MHz}$ band in Delhi Circle
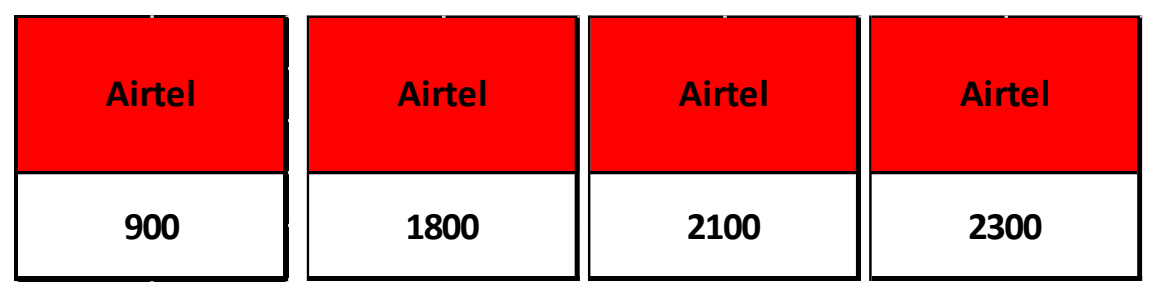
$3^{\text {rd }}$ International Conference on

SOCIAL SCIENCES IN THE 21ST CENTURY

Table 5

Total Licensed Spectrum in Various Countries (in MHz)

\begin{tabular}{|l|l|l|l|}
\hline Country & Current & Pipeline & $\begin{array}{l}\text { Hzl } \\
\text { Subscriber }\end{array}$ \\
\hline USA & 608 & 55 & 2.1 \\
\hline Germany & 615 & 0 & 6.2 \\
\hline France & 555 & 50 & 9.3 \\
\hline Brazil & 554 & 0 & 2.0 \\
\hline Japan & 500 & 10 & 3.3 \\
\hline Australia & 478 & 230 & 22.8 \\
\hline UK & 353 & 265 & 7.9 \\
\hline China & 227 & 360 & 0.5 \\
\hline
\end{tabular}




\section{SOCIAL SCIENCES IN THE 21ST CENTURY}

Table 6

Spectrum Price in Various Bands in India

\begin{tabular}{|l|l|l|l|l|l|l|l|l|}
\hline & $\mathbf{7 0 0} \mathbf{M H z}$ & $\begin{array}{l}\mathbf{8 0 0} \\
\mathbf{M H z}\end{array}$ & $\begin{array}{l}\mathbf{9 0 0 M H} \\
\mathbf{z}\end{array}$ & $\begin{array}{l}\mathbf{1 8 0 0} \\
\mathbf{M H z}\end{array}$ & $\begin{array}{l}\mathbf{2 1 0 0 M} \\
\mathbf{H z}\end{array}$ & $\begin{array}{l}\mathbf{2 3 0 0 M} \\
\mathbf{H z}\end{array}$ & $\begin{array}{l}\mathbf{2 5 0 0 M} \\
\mathbf{H z}\end{array}$ & Total \\
\hline $\begin{array}{l}\text { Pricing } \\
\text { (in Cr) }\end{array}$ & 57,425 & 29,095 & 45,583 & 14,365 & 18,730 & 16,340 & 16,340 & $1,97,8$ \\
\hline
\end{tabular}

Table 7

Taxes and Levies in Telecom Sector in India and its Neighbouring Countries

\begin{tabular}{|c|c|c|c|c|c|c|}
\hline $\begin{array}{l}\text { Regulatory } \\
\text { Charges }\end{array}$ & Pakistan & Sri Lanka & China & Malaysia & Bangladesh & India \\
\hline $\begin{array}{l}\text { Service Tax, } \\
\text { GST }\end{array}$ & $\begin{array}{l}18-\quad 19.5 \% \\
\text { (Sales Tax) }\end{array}$ & $\begin{array}{l}25.51 \% \\
\text { Telecom Levy } \\
\text { (VAT + MSL+ } \\
\text { NBT+ECL) }\end{array}$ & $\begin{array}{l}11 \% \\
\text { (VAT) }\end{array}$ & $6 \%$ (GST) & $\begin{array}{l}19.45 \% \\
\text { (Supplementary } \\
\text { duty+VAT+ } \\
\text { Surcharge) }\end{array}$ & $\begin{array}{l}14 \% \text { (Service } \\
\text { Tax) +0.5\% } \\
\text { (Swachh } \\
\text { Bharat cess) } \\
+0.5 \% \text { Krishi } \\
\text { Kalyan Cess }\end{array}$ \\
\hline License Fee & $\begin{array}{l}0.5 \% \text { LF + } \\
0.5 \% \\
\mathrm{R} \& \mathrm{D}\end{array}$ & $2.04 \%$ & - & $0.5 \%$ & $\begin{array}{l}\text { 5.5\% AGR + } \\
\text { BDT 50mn (per } \\
\text { 2G \&3G license }\end{array}$ & $8 \%$ \\
\hline SUC & Cost recovery & - & - & - & - & $2-6 \%$ \\
\hline USO Fund & $\begin{array}{l}1.5 \% \text { of gross } \\
\text { revenue }\end{array}$ & - & - & $\begin{array}{l}6 \% \text { of } \\
\text { weighted } \\
\text { net revenue }\end{array}$ & $1 \%$ of AGR & $\begin{array}{l}5 \% \text { included } \\
\text { in license fee }\end{array}$ \\
\hline
\end{tabular}




\begin{tabular}{|c|c|c|c|c|c|c|}
\hline Other Taxes & $\begin{array}{ll}\text { Sales tax of } \\
\text { PKR } 250 \text { on } \\
\text { new r or } \\
\text { replacement } \\
\text { SIM }\end{array}$ & $\begin{array}{l}\text { LKR 3/Min } \\
\text { IDD Levy }\end{array}$ & - & - & $\begin{array}{ll}\text { SIM Tax } & \text { of } \\
\text { BDT } 100 \text { on } \\
\text { New } & \text { or } \\
\text { Replacement } & \\
\text { SIM } & \end{array}$ & - \\
\hline $\begin{array}{l}\text { Telecom } \\
\text { Levy }\end{array}$ & $\begin{array}{l}20.5 \%-22 \%+ \\
\text { Cost } \\
\text { recovery+ } \\
\text { SIM Tax }\end{array}$ & $\begin{array}{l}27.55 \%+\text { IDD } \\
\text { Levy }\end{array}$ & $11 \%$ & $12.5 \%$ & $\begin{array}{l}25.95 \%+\text { BDT } \\
50 \text { Min per } \\
\text { License + SIM } \\
\text { Tax }\end{array}$ & $25-29 \%$ \\
\hline $\begin{array}{l}\text { Telecom } \\
\text { Specific } \\
\text { Levy }\end{array}$ & $\begin{array}{l}2.5 \%+\text { Cost } \\
\text { Recovery + } \\
\text { SIM Tax }\end{array}$ & $\begin{array}{l}12.04 \%+\text { IDD } \\
\text { Levy }\end{array}$ & - & $0.5 \%$ & $\begin{array}{lr}6.5 \%+\text { BDT } 50 \\
\text { Min } & \text { Per } \\
\text { License+ } & \text { SIM } \\
\text { Tax } & \end{array}$ & $10-14 \%$ \\
\hline
\end{tabular}

\section{Figure 1}

\section{Telecom Circles in India}

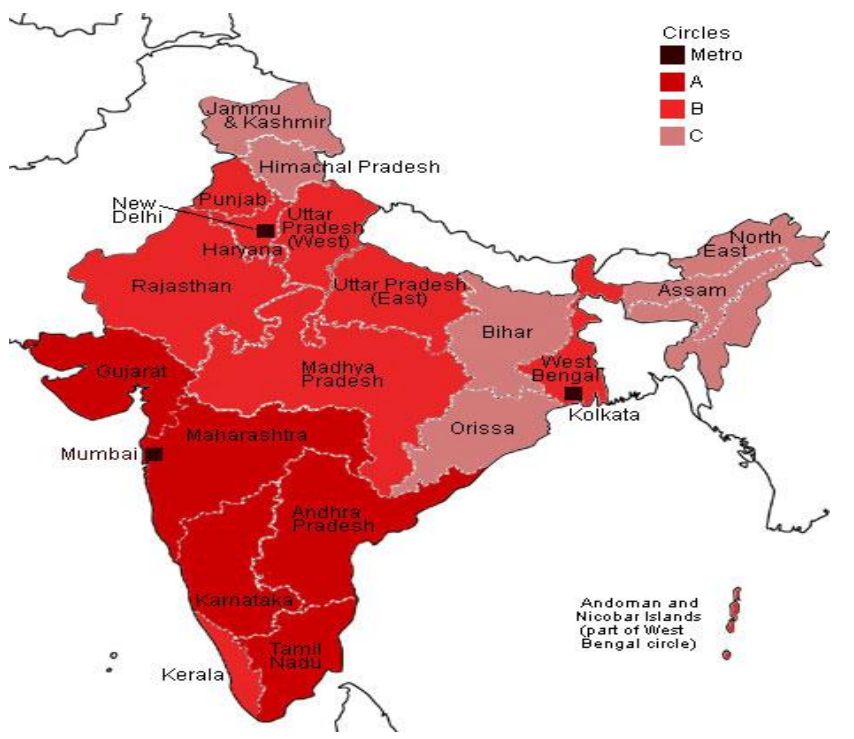

Figure 2

\section{Herfindahl-Hirschman Index (HHI}




\section{SOCIAL SCIENCES IN THE 21ST CENTURY}

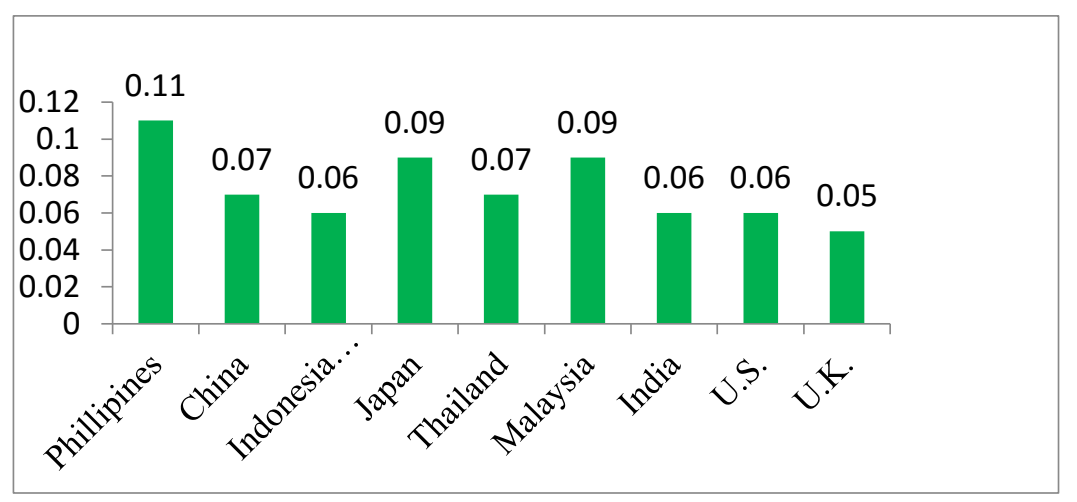

Figure 3

Income from Spectrum Auctions (INR Crore)

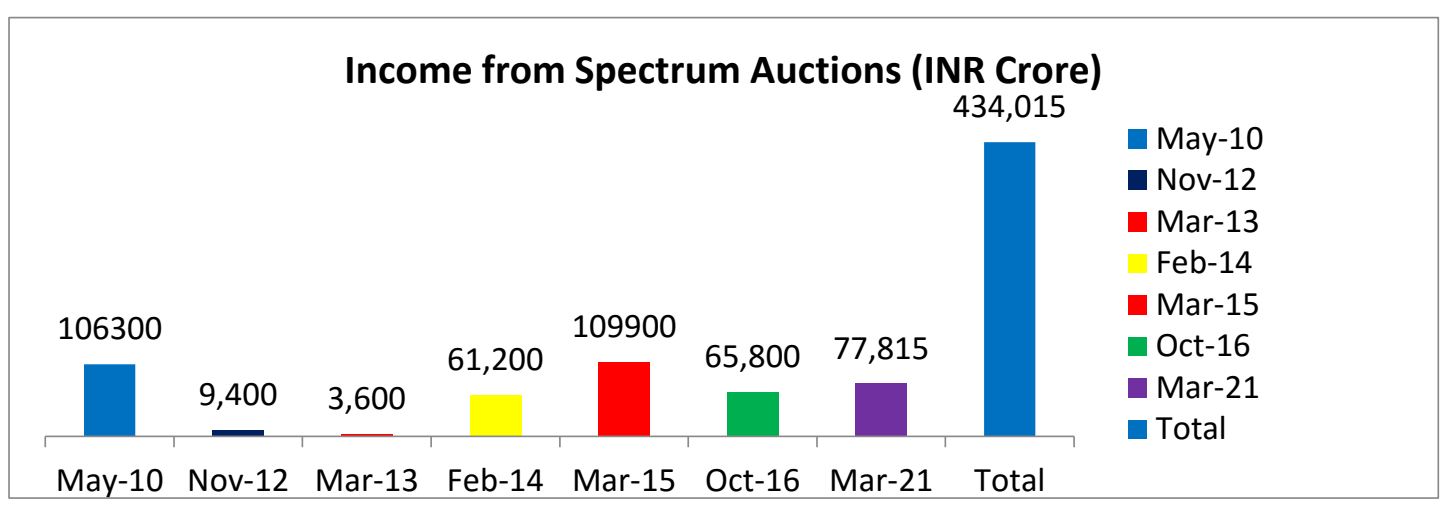

\section{Figure 4}

Debt of Telecom Industry (in '000 Cr)

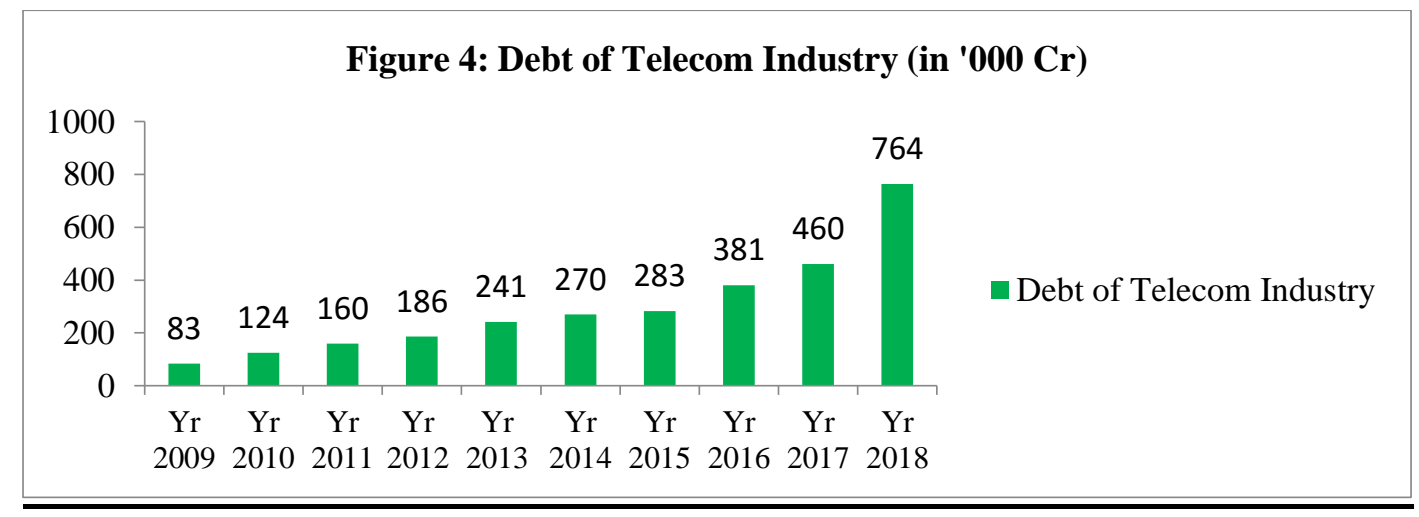

